\title{
Preparing for the 26th International Conference of the Red Cross and Red Crescent
}

The Hungarian Red Cross will host the 26th International Conference of the Red Cross and Red Crescent to be held in Budapest in November/December 1991.

The representatives of States party to the Geneva Conventions and of the components of the International Red Cross and Red Crescent Movement attending the Conference will be invited to discuss such key issues as respect for international humanitarian law (IHL) and the activities of the ICRC; the implementation, promotion and development of IHL; development; Red Cross and Red Crescent response to natural and technological disasters and the problem of refugees.

The Review will devote its January-February 1992 issue to the proceedings and conclusions of the Conference and other statutory meetings of the Movement. We have the pleasure to publish an article by Mr. Rezso Sztuchlik, President of the Executive Committee and Secretary General of the Hungarian Red Cross, who has been kind enough to express his thoughts on major topics of the Conference and on the new challenges facing his National Society.

The Hungarian Red Cross is greatly honoured to have been chosen as the host for the 26th International Conference. It is the first time, during the Society's 110 years in existence, that the Conference is being organized in Budapest. What does it represent for us, and what do we expect of it?

First of all we would like to offer to all our Red Cross and Red Crescent friends such hospitality and working conditions that they will be able to make good use of this opportunity for the further development of our worldwide humanitarian Movement. We are confident that, with many parts of central and eastern Europe in turmoil, the conditions of stability in Hungary will help delegates in this undertaking. The events of recent years and months justify a thorough analysis of our action and the conditions in which we work. Let me share some of our concerns with you. 


\section{The world environment}

We have to recognize that in our world of today, despite the development of international political and legal instruments and institutions aimed at ensuring that political, economic, ethnic, religious and other tensions and disputes are dealt with through bilateral and multilateral negotiation, there is a continuing tendency to resort to violence in an attempt to "settle" internal and international conflict situations. This confirms what the Tansley Report suggested back in 1975, i.e. that the world may have crossed the boundary into a state of permanent emergency, bringing with it increased vulnerability and instability. Tansley's conclusions were that:

1. disasters are likely to occur with more frequency and with greater impact;

2. new types of disasters may be expected; and

3. conflict situations are likely to increase.

As I pointed out in a study written jointly with Anja Toivola, this forecast proved correct. Recent and current events confirm it even more. The easing of global tensions, the phasing out of the cold war may lead to individuals and groups standing up more firmly for their rights, tolerating authoritarian regimes to a lesser degree, and lead therefore to an increase in internal tensions and conflicts. ${ }^{2}$

On the one hand we can welcome with justified sympathy the fact that in significant parts of the world changes toward democratic institutions and legality are writing a new chapter in contemporary history, and also offer more freedom of action for our Movement to act according to our principles in these territories. On the other hand many (suppressed) tensions are now coming to the surface and creating new challenges for our humanitarian commitment, often outside the scope of classic emergency situations. Let us keep in mind that tradition is one of the strengths of our Movement when it urges us to use past experiences and a sense of humanitarian initiative in determining current and future tasks and roles, but it can be a disadvantage if it is lived through as an obstacle to adapting to changing situations.

1 D. Tansley: Final Report: An Agenda for Red Cross, Geneva, 1985, pp. 55-58.

2 R. Sztuchlik and A. Toivola, What was the impact of the Tansley Report?, Henry Dunant Institute, Geneva, 1988, p. 18. 


\section{Major topics and issues at stake}

As for the issues to be discussed, it is of course not possible to comment on all of them. May I therefore only mention those which I see as the most urgent today.

One is the possibility for our Movement to be able to act whenever its intervention is required under the Geneva Conventions, and the role of the various components of our Movement as laid down in its Statutes. An important part of the responsibility here lies with the governments, i.e. to accept and respect the fact that access for the Red Cross/Red Crescent to the victims can under no circumstances be subject to political bargaining and reciprocity.

The second is to decide on the means for an expansion of our capacity of action in the nineties, especially in areas where there is a clear link between basic human rights and our humanitarian commitments. I consider as part of these questions the problem of torture, refugees, the individual and collective rights of ethnic, religious and other minorities, and women's rights.

As for the capacity of our Movement to fulfil its role as a unique humanitarian organization with a special status, we cannot be complacent and should admit that whether we shall or shall not be in a position to face the increasing need for humanitarian services in our times will largely depend on our ability and determination to better harmonize and utilize our common resources. At all levels and in all of our Red Cross/Red Crescent bodies, we should be aware of ourselves as being part of our worldwide Movement that has been able to identify with and act according to universally shared values and principles for well over a century, and this awareness should be reflected more strongly in our behaviour. Our Fundamental Principles should be seen as an everyday guide in all we do. We have to find the means, and I hope the Strategy for the Nineties will help in this, of joining our efforts at local, national and international levels in order to be more efficient both in conflict situations and in peacetime activities.

A painful experience in recent times has been the misuse of and/or lack of respect for our emblem. We ourselves have been confronted with such misuse during some of the operations in which our National Society was involved, and we would find support from the Red Cross/Red Crescent community extremely valuable in backing up our efforts to prevent it.

\section{Priorities for Red Cross action in Hungary}

The Hungarian Red Cross wishes to be a reliable and constructive partner in the processes and programmes outlined above, guided solely by our independent humanitarian commitment. This international Red Cross/Red Crescent 
solidarity also gives us strength to better perform our mission in Hungary. Over the last two years, the political changes that have taken place have presented new challenges to our Society, not only in taking up programmes corresponding to the most urgent needs, but also in building stronger credibility for our services and asserting and strengthening our position as an independent National Society. This we are doing in a rapidly changing political situation where everything that existed under the past regime has naturally been questioned, and where many erstwhile organizations have disappeared. We decided to concentrate on the services we were to offer to the population, to use the newly acquired political freedoms to initiate new programmes, especially social assistance programmes to help the poor and the needy, and thus, in addition to offering better services, also to strengthen our credibility in public opinion. At the same time, while being ready to intensify our co-operation with any humanitarian, religious, political or other organizations within the limits of the Red Cross Principles, we have avoided any move to be seen as politically pro-government or pro-opposition. As a result the various political forces present have also accepted us as an independent humanitarian organization, specialized in its field and endorsed by a decision of parliament which reconfirmed the validity of the special law governing our Society.

A I mentioned above, it was especially in the area of social assistance to the poor and the needy that we have had to improve our services. We have opened free-meal services, which now provide more than 2,000 needy people with free hot meals daily. We have set up aid programmes (food and clothing) which were well received by the public. The value of these programmes is shown by the fact that many are now co-financed by local authorities and for many of them we can find corporate and/or individual sponsors.

Our refugee assistance work has been another major task. Started back in 1987 with refugees from Romania, it continued with refugees from the Middle East, then from the former German Democratic Republic, Czechoslovakia, and the Soviet Union, and currently from Yugoslavia. In all over 30,000 refugees have received Hungarian Red Cross assistance over the past four years.

Until 1989 half of our financial resources were raised by ourselves, the other half consisting of government subsidies. Now, two thirds are raised by us, whilst one third is a subsidy voted by parliament and is therefore exempt from any risk of political influence. A traditional activity in which we have maintained our position is the recruitment of blood donors; despite worsening conditions (more needy and unemployed people), we have managed to stabilize the number of donors, which is quite good by international standards ( 52 per 1,000$)$. 
As for our structure, in June 1990 we decided to decentralize our organization so that decisions would be made where the problems really arise. This decentralization has freed new energies and increased the sense of humanitarian initiative and responsibility within our local branches. A continuing weakness is the insufficient number of trained volunteers, the inability of some of our staff to use fully the new possibilities of development and their recently acquired wider powers and, despite the progress we have made, the still inadequate level of disaster preparedness.

I hope that I have thus been able to give you an insight into our situation, programmes and present concerns. We shall receive you in Hungary with an open mind, feeling confident that with a true Red Cross/Red Crescent spirit we shall be able to prepare our Movement for the formidable challenges of the nineties. Welcome to Budapest 1991.

\section{Rezso Sztuchlik}

President of the Executive Committee

and Secretary General

Hungarian Red Cross 